\title{
REVIEW
}

\section{Enzyme markers: their linkage with proteins and use in immuno-histochemistry}

\author{
STRATIS AVRAMEAS ${ }^{\star}$ \\ Laboratoire Chimie des Protéines, \\ Institut de Recherches Scientifiques sur le Cancer Villejuif, France
}

Received 5 May 1972

\section{Contents}

Synopsis

Introduction

Methods available

(a) Antisera and antibodies

(b) Enzyme-markers

(c) Cross-linking agents for the coupling of enzymes to antibodies

(d) Modifications of the enzyme-labelled antibody technique

Light microscopy

Electron microscopy

Quantitative techniques with enzyme-labelled proteins

Conclusions

Synopsis. The preparation and use of enzyme-labelled antibodies and antigens is described. First, the enzyme is linked covalently to the antibody or antigen. Next, the enzyme-labelled protein is allowed to react with the cellular antigen or antibody; and finally, the sites of bound enzyme are revealed with appropriate cytochemical staining techniques at either the light or electron microscopical levels.

Because the specific activity of an enzyme can be assayed by appropriate enzymological techniques, enzyme-labelled antibodies can also be employed for measuring the amounts of cellular constituents. Similarly, enzyme-labelled antigens can be used for the quantitation of humoral antigens.

In addition to the antigen-antibody reaction, enzyme markers can also be used for the quantitation and localization of other specifically interacting constituents.

* Present address: Unité d'Immunocytochimie, Département de Biologie Moléculaire, Institut Pasteur, 28 rue du Dr. Roux, 75-Paris XV $\mathrm{XV}^{\circ}$, France. 


\section{Introduction}

Since immunofluorescence was introduced by Coons \& Kaplan (1950) as a technique for the localization of cellular constituents, considerable progress in immunocytological procedures has been achieved. The common feature of all these procedures is a marker substance which is attached to an antibody, visible at the light or electron microscope levels or both. The labelled antibody preparation is then used for the detection of particular cellular constituents. Fluorescent (Coons, 1956) and radioactive (Berenbaum, I959) substances, ferritin (Singer, I959) and heavy metals (Pepe, I96I) have been used as the markers.

The detection of cellular constituents at the light microscope level has been carried out mainly with the immunofluorescence technique while the immunoferritin method has been used almost exclusively for ultrastructural studies.

More recently, the use of enzymes as markers was introduced (Nakane \& Pierce, I966; Avrameas \& Uriel, I966). In these procedures, the enzyme is first covalentlylinked to the antibody; then the enzyme-labelled antibody is allowed to react with the cellular antigen and finally, the sites of enzyme activity are revealed by appropriate cytochemical methods. Since specific cytochemical techniques for staining enzymes are available both for light and electron microscopy, enzyme-labelled antibodies can be employed equally well for microscopic studies at the two levels.

\section{Methods available}

When dealing with enzyme-immunocytochemical methods, one should bear in mind that the choice of the three basic elements, namely antibody, enzyme, and cross-linking reagent, is of major importance.

\section{(a) Antisera and antibodies}

For the labelling, either the gamma-globulin fraction from immune sera or specifically purified antibodies can be used. The best results in both cases are obtained when the starting material is a hyperimmune serum containing high levels of antibody. Although satisfactory results can be obtained and have been reported (Benson et al., 1970; Fukuyama et al., 1970; Petts \& Roitt, 1971) with immune gamma-globulins, it is preferable to employ, whenever possible, pure antibodies. The results obtained with pure labelled-antibodies are much more reproducible and non-specific background staining is much less pronounced.

The isolation of pure antibodies is accomplished by the use of the immunoadsorption techniques, using water insoluble protein derivatives (Silman \& Katchalski, 1966). An easy way to prepare them is to employ glutaraldehyde (Avrameas \& Ternynck, 1969). The protein to be insolubilized is dissolved in a buffer of near neutral $\mathrm{pH}$. Then glutaraldehyde is added and a gel will form to to 30 min later, depending on the protein. After dispersion, homogenization and washing, the polymer is ready for use as an immunoadsorbent for the isolation of antibodies. It is worth while noting that by using glutaraldehyde, all the proteins present in a serum, or in a biological fluid, in general will be insolubilized. These insoluble derivatives can be employed successfully in the preparation of monospecific antisera or the isolation of specific antibodies. 
Another simple way of preparing immunoadsorbents is to couple proteins to polyacrylamide beads activated with glutaraldehyde (Ternynck \& Avrameas, 1972). By this procedure, small quantities of antigen are sufficient to prepare effective immunoadsorbents.

\section{(b) Enzyme markers}

Obviously, any enzyme that is detectable by histochemical methods (Pearse, 1960) and that does not modify the structure of the cell can be utilized as a marker. However, the enzyme to be used as the label should possess one, if not all, of the following criteria: first, a high specific activity and turnover number; second, a relatively high stability at room temperature; third, it should not lose a substantial part of its activity after a coupling procedure; and finally, it should be commercially available. This explains why at present the enzymes that can be used as labelling substances are limited to a small number. Amongst them, horseradish peroxidase is the enzyme of first choice. E. Coli alkaline phosphatase and Aspergilus niger glucose oxidase, although not often employed, have also given reproducible and satisfactory results (Avrameas, 1969; Avrameas et al., 1971). Specific cytochemical techniques for localizing these enzymes are available for both light and electron microscopy (Graham \& Karnovsky, 1966; Hugon \& Borgers, I966; Kühlmann \& Avrameas, I97I). However, staining for peroxidase as compared to the two other enzymes, permits a more precise localization and identification of ultrastructures, and it is for this reason that peroxidase is almost exclusively employed in electron microscopy.

(c) Cross-linking agents for the coupling of enzymes to antibodies

For the coupling of enzymes with antibodies, the following cross-linking agents have been employed: $p, p^{\prime}$-difluoro- $m, m^{\prime}$-dinitrophenyl sulphone and water-soluble carbodiimides (Nakane \& Pierce, I967); tetrazotized $c$-dianisidine, cyanuric chloride and glutaraldehyde (Avrameas, 1968). In our hands, the most satisfactory and reproducible results were obtained with glutaraldehyde by employing the following technique: the antibody and the enzyme to be coupled are dissolved in a phosphate buffer of near neutral $\mathrm{pH}$ and then glutaraldehyde is added dropwise to the stirred solution. After $3 \mathrm{hr}$, the solution is dialyzed, centrifuged and stored at $4{ }^{\circ} \mathrm{C}$ until required for use (Avrameas, I968, I969a). Using this procedure, several enzymes have been coupled to various antibodies and the conjugates obtained were found to be highly effective for the immunohistochemical detection of the corresponding antigens. The conjugates remained immunologically and enzymatically active, even after two years of storage at $4^{\circ} \mathrm{C}$. Experiments performed using several techniques have shown that the enzyme antibody conjugates prepared with glutaraldehyde were composed of a highly heterogeneous population of complexes but that free antibody was absent in the reaction mixture. The average ratio of antibody to the enzyme in the active complexes varied between I and 3 .

Recently, a two-step procedure was developed which uses glutaraldehyde to prepare both peroxidase-antibody and peroxidase-Fab conjugates (Avrameas \& Ternynck, 1971). This procedure is based on the observation that peroxidase alone cannot be insolubilized even with an excess of glutaraldehyde. In fact, peroxidase possess few lysine residues (Welinder et al., I972), residues with which almost exclusively glutaraldehyde reacts, and probably most of them have the $\varepsilon$-amino group blocked. Thus, when glut- 
araldehyde is added in excess to a solution of peroxidase, it is conceivable that most of the glutaraldehyde reacts with the free amino groups of peroxidase only by one of its two active aldehyde groups. The remaining free aldehyde group should then be available for combination with the amino groups of a protein added subsequently.

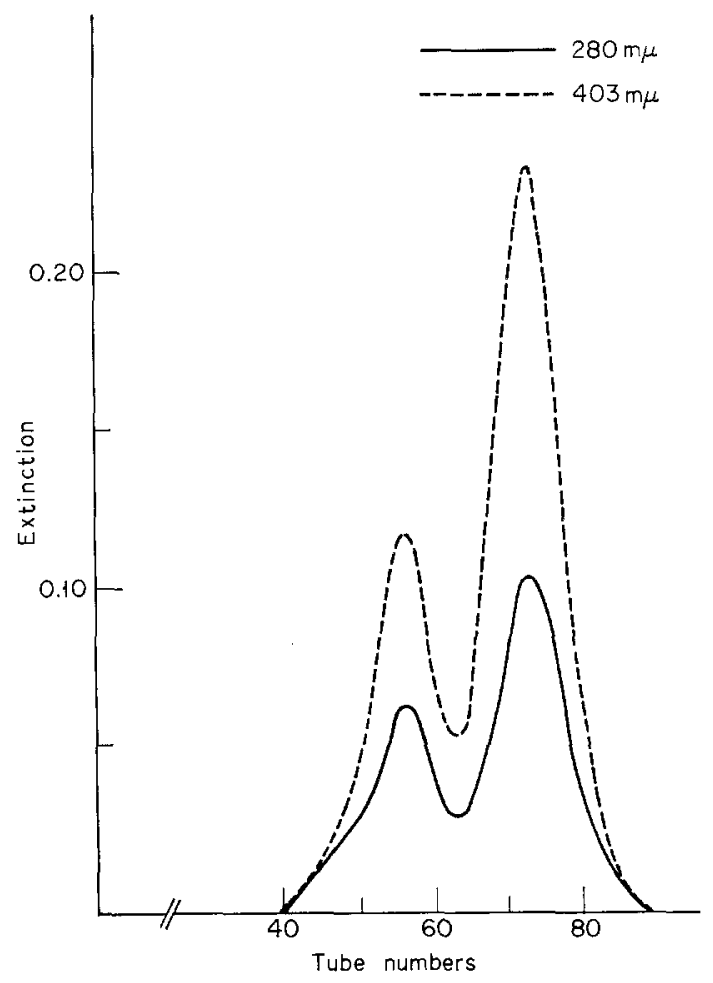

Figure I. Chromatography on Sephadex G-200 column (IOO $\times 2 \mathrm{~cm}$ ) equilibrated with $0.1 \mathrm{M}$ phosphate buffer, $\mathrm{pH} 6.8$, and calibrated for mol. wt. determinations of peroxidase-labelled sheep Fab anti-rabbit IgG prepared by the two-step procedure. The first peak corresponds to a mol. wt. of 80000 and the second to one of 40000 . $(-)$ is extinction at $280 \mathrm{~nm}$ and (----) extinction at $403 \mathrm{~nm}$ ). Extinction values at $403 \mathrm{~nm}$ reveal the chromatographic profile of peroxidase (see Avrameas \& Ternynck, 197I).

To couple peroxidase to antibody by this procedure, the peroxidase is first dissolved in a phosphate buffer near neutrality and then an excess of glutaraldehyde is added. The reaction mixture is allowed to stand at room temperature overnight and filtered through a Sephadex G-25 column in order to remove the excess of unreacted glutaraldehyde. The peroxidase preparation in which now active aldehyde groups have been introduced is allowed to react at $\mathrm{pH} 9.5$ with the antibody or its Fab fragments. Ultracentrifugal analysis, chromatography on Sephadex G-200 columns equilibrated for mol. wt. determinations and sodium dodecyl sulphate-acrylamide electrophoresis have shown that, by 
this procedure, only a homogeneous population of conjugate is obtained in which the molar ratio of antibody or Fab to peroxidase is I: I (Avrameas \& Ternynck, I97I). It is interesting to note that treatment of peroxidase with glutaraldehyde stabilizes the enzyme considerably. Thus, the glutaraldehyde-treated peroxidase is stable under strong denaturating conditions under which the native peroxidase completely loses its catalytic activity. Furthermore, when peroxidase was coupled with other proteins (albumin, soya bean trypsin inhibitor, insulin) using the above procedure, homogeneous populations of conjugates were always obtained in which the molar ratio of peroxidase to the protein was $I: I$.

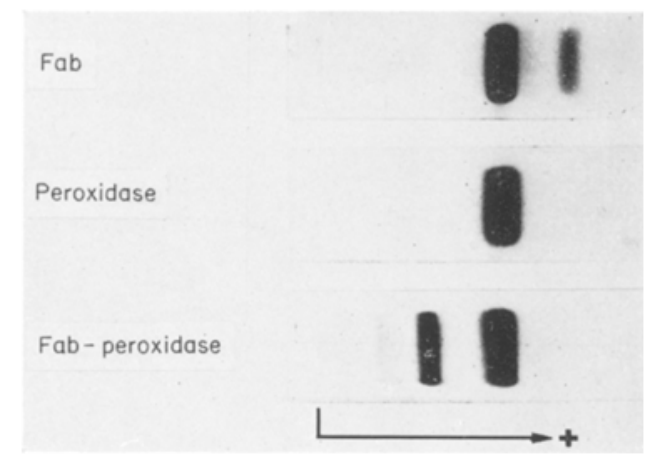

Figure 2. Sodium dodecyl sulphate-acrylamide gel electrophoresis of sheep Fab antirabbit IgG; peroxidase; and peroxidaselabelled sheep Fab anti-rabbit IgG prepared by the two-step procedure. After coupling, mainly two electrophoretic bands are seen. The more anodic band corresponds to a mol. wt. of 40000 and the less anodic one to 80000 (see Avrameas \& Ternynck, I97I).

(d) Modifications of the enzyme-labelled antibody technique

In order to avoid coupling procedures or to increase the sensitivity, several variants of the enzyme-labelled antibody technique have been developed (Avrameas, r969b; Mason et al., 1969; Sternberger \& Cuculis, 1969). These procedures are based on the principle that enzyme-antienzyme complexes always possess catalytic activity, hence permitting the detection of the enzyme in the immunological complexes (Uriel, 1967). Thus, hybrid antibodies possessing double anti-immunoglobulin antienzyme specificities have been employed for the detection of immunoglobulins and antienzyme antibodies were used to enhance the sensitivity of the immuno-enzyme techniques (Avrameas, 19696). The more characteristic of these procedures is as follows. An anti-immunoglobulin antibody reacts with the immunoglobulin of species $A$, which is present in a fixed cell in an insoluble form, only by one of its two active sites. Thus, the free active site of the antiimmunoglobulin antibody can link the subsequently added anti-enzyme antibody that was prepared in species A. This anti-enzyme antibody can now bind the finally added enzyme. As the enzyme-antienzyme complex possesses catalytic activity, this allows the cytochemical detection of the enzyme and consequently, the immunoglobulin of species A. Because antibodies are immunoglobulins, it is evident that this procedure allows the detection of any antigen (Avrameas, I969 $b$; Mason et al., I969; Sternberger \& Cuculis, 1969).

\section{Light microscopy}

At the light microscope level, the enzyme-labelled antibody technique has been applied with success in various immunocytological studies. Thus, antibodies of various species 
and specificities were coupled with enzymes and utilized to detect the corresponding antigens (Nakane, 1968, 1970; Baker et al., 1970; Benson et al., 1970; Fukuyama et al., 1970; Avrameas, 1968, I969a; Druhet et al., r970; Bariety et al., 1971 ; Zeromski, I970). Conversely, antigens were coupled with enzymes and employed for detecting antibodies (Avrameas, 1968, I969a; Johnson et al., I97I). In these studies, the localization of antigens or antibodies was carried out on imprints, cell suspensions or tissue sections after adequate fixation. The best results were obtained when dehydrating fixatives like ethanol or acetone were used but good results have also been reported when formaldehyde was used as the fixative (Wicker \& Avrameas, 1969). Because for enzymes, histochemical staining techniques giving rise to final reaction products of various colours are available, enzyme-labelled antigen or antibody can be used for the simultaneous detection of two different cellular constituents (Avrameas, I969a; Avrameas et al., I971; Nakane, I968; Wicker \& Avrameas, 1969). Alternatively, paired staining techniques combining autoradiography or immunofluorescent and immuno-enzymological methods can be employed for the simultaneous or two-step detection of two constituents (Guillien et al., 1968, 1970; Wicker \& Avrameas, 1970). Comparison of peroxidase- and fluoresceinconjugated antisera have shown that the sensitivities of both methods were similar and that the localization of the antigen by the two labels were identical (Avrameas, I969; Benson et al., 1970; Petts \& Roitt, I971 ; Wicker \& Avrameas, 1969).

\section{Electron microscopy}

Satisfactory and reproducible results have been obtained when the peroxidase-labelled antibody technique was applied for the ultrastructural localization of cell surface antigen (Bretton \& Lespinats, r969; Bretton et al., r972; Gonatas et al., 1972). Equally satisfactory results were obtained when the modification of the peroxidase-labelled technique described earlier was used (Willingham et al., 197I).

A systematic comparison between ferritin-labelled and peroxidase-labelled antibody for the localization of cell surface antigens has shown that the peroxidase technique reveals more antigenic determinants than the ferritin one and is several times more sensitive (Bretton et al., I972).

When the immunoenzymatic procedures were tested for their capacity to reveal intracellular antigen at the ultrastructural level, satisfactory, but very often inconsistant, results were obtained (Kawarai \& Nakane, 1970; Leduc et al., 1969a; Nakane \& Pierce, I967; Wolff \& Schreiner, I97I). This was mainly due to penetration difficulties of the conjugates into the interior of cells fixed by fixatives routinely employed in electron microscopy. In our hands, the most satisfactory results were obtained when Fabperoxidase conjugates prepared by the two-step procedures described above were used (Kühlman et al., 1972). It must be stressed, however, that although these conjugates are noticeably more effective for the ultrastructural localization of antigens and good results are obtained, difficulties of penetration always persist.

Recently, Fab-antibody fragments labelled either with cytochrome $\mathrm{C}$ or peroxidase were compared for their effectiveness for the ultrastructural localization of antigens (Kraehenbuhl et al., I97I). Both markers revealed the antigen equally well but a heavier background was reported to occur with peroxidase. In this connection, it should be stressed once more that for all immunoenzymatic techniques, the most purified peroxi- 
dase preparation $\left(R Z^{\star}=3\right)$ should be used in order to reduce or avoid non-specific staining and it appears more than probable that an impure peroxidase preparation $(\mathrm{RZ}=0.6)$ was employed by Kraehenbuhl et al. It seems to me that in ultrastructural immunoenzymatic techniques, the limiting factor is rather the shape of the antibody or its $\mathrm{Fab}$ fragment rather than the mol, wt. of the label used. In my opinion, further improvements for the ultrastructural localization of antigens should be focused instead on the use of new fixatives and embedding media for electron microscopy.

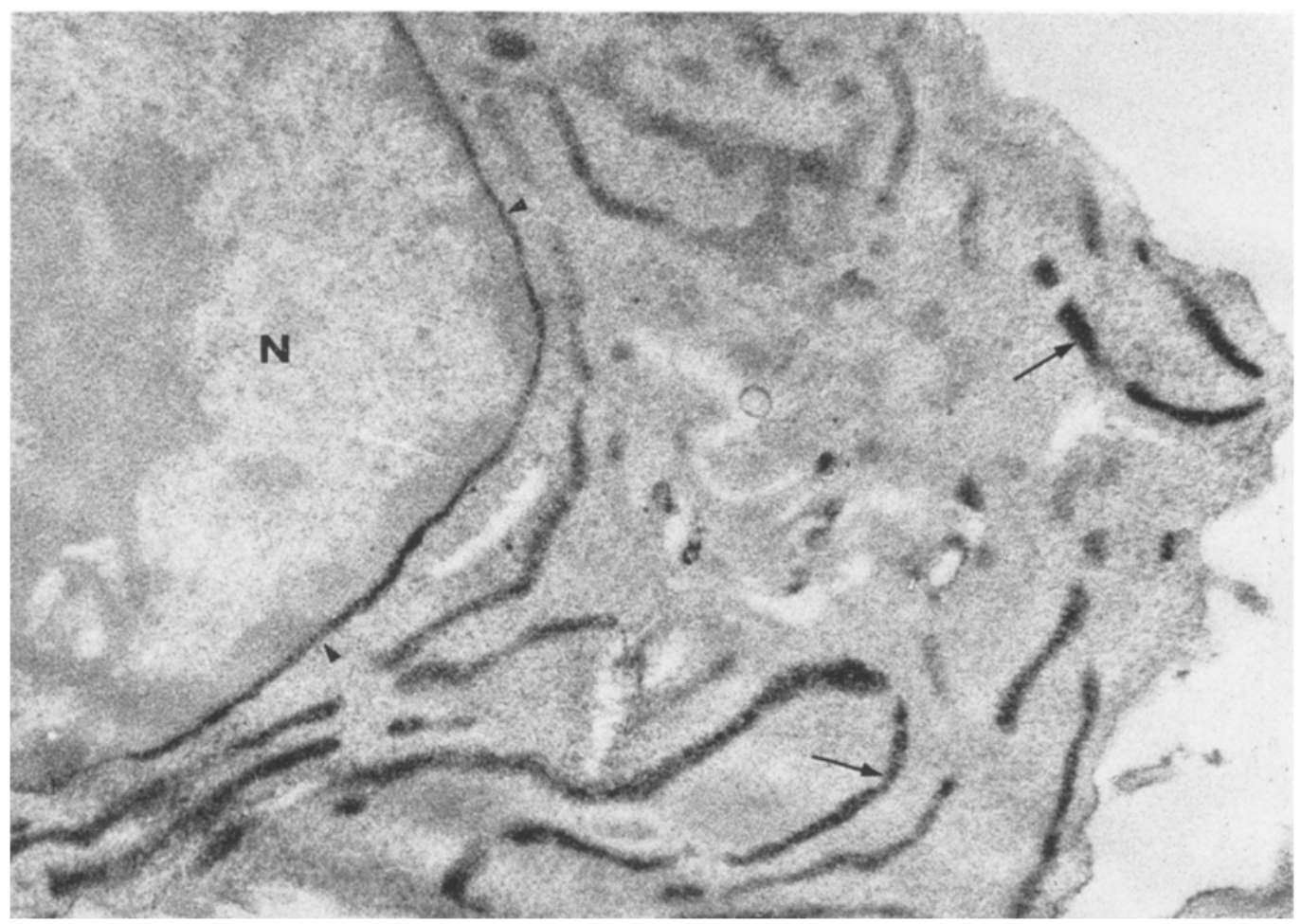

Figure 3. Detection of immunoglobulins in rabbit lymph node by the use of sheep Fab anti-rabbit immunoglobulins labelled with peroxidase. Peroxidase reaction positive in perinuclear space (A) and in the ergastoplasmic cisternae (arrows); $N=$ nucleus $\times 18$ ooo from Kühlman et al. (1972), ms. in preparation.

\section{Quantitative techniques with enzyme-labelled proteins}

The quantity of an enzyme present in a cell can be accurately determined if use is made of the procedure currently employed in enzymology for the measurement of the catalytic activity of enzymes. It appears then that an enzyme-labelled antibody can be used to measure the activity of cellular constituents. Thus, rabbit antibodies anti-rat $\operatorname{IgG}$ labelled with peroxidase have been employed for the dosage of the antigenic determi-

* RZ (German Reinheit Zahl) is the ratio of the extinctions at $403 \mathrm{~nm}$ (haemin) and $275 \mathrm{~nm}$ (protein) of a peroxidase and indicates the degree of purity of peroxidase. For pure crystalline horseradish peroxidase $\mathrm{RZ}$ is almost 3 . 
nants of rat IgG present at the surface of lymphoid celis (Avrameas \& Guilbert, 1971a). Cell suspensions from lymph nodes were prepared and a given number of cells were incubated for various periods of time at $4{ }^{\circ} \mathrm{C}$ with increasing concentrations of peroxidaselabelled antibody. The cells were washed by centrifugation and the peroxidase activity of the cellular preparation was determined spectrophotometrically. Knowing the number of the cells, the total quantity of peroxidase fixed by these cells and the ratio of peroxidase to antibody, the mean quantity of antibody fixed per lymphoid cell was calculated. It was thus found that each lymphoid cell carrying IgG possess approximately 230,000 IgG antigenic determinants on its surface.

Recently, peroxidase- and alkaline phosphatase-labelled antigens were also employed for the quantitation of humoral constituents (Avrameas \& Guilbert, I97I $b$; Engvall \& Perlmann, I97I; Van Weemen \& Schuurs, I97I). These procedures are based on the same principles as those developed for quantitative radioimmunoassays. Thus, a fixed quantity of an enzyme-labelled antigen is incubated with increasing concentrations of an unlabelled one in the presence of a given amount of antibody directed against this antigen. The methods seem quite promising since by these assays, $\mathrm{I}-\mathrm{I} / 0 \mathrm{ng} / \mathrm{ml}$ of antigen could be determined.

\section{Conclusions}

It appears that the main advantage of the immunoenzyme techniques is the fact that the same reagent, namely the peroxidase-labelled antigen or antibody, can be employed both for quantitative studies and qualitative work at the light and electron microscope levels. In consequence, the results obtained by the different procedures can be directly linked and interpreted objectively.

The use of an enzyme-labelled antibody for the detection of an antigen is based on the general principle that antibodies react specifically with their corresponding antigens. In addition to the antigen-antibody reaction, there are other systems where analogous procedures may be employed. Thus, a procedure using concanavalin $\mathrm{A}$, a saccharide-binding protein, and peroxidase has been developed for the quantitation and the light and electron microscopic localization of cellular carbohydrate components (Avrameas, I970; Bernhard \& Avrameas, I97I). Furthermore, peroxidase-labelled soya bean trypsin inhibitor has been employed for the detection of trypsin in pancreatic cells; and plant agglutinins conjugated with peroxidase have been used for the light and electron microscopic detection of specific cellular carbohydrate components (Gonatas \& Avrameas, 1972).

\section{References}

avrameas, S. (1968). Detection d'anticorps et d'antigènes à l'aide d'enzymes. Bull. Soc. Chim. Biol. 50, I $169-78$.

AVRAMEAS, S. (r969a). Coupling of enzymes to proteins with glutaraldehyde. Use of the conjugates for the detection of antigens and antibodies. Immunochemistry 6, 43-52.

AVRAMEAS, s. $(1969 b)$. Indirect immunoenzyme techniques for the intracellular detection of antigens. Immunochemistry 6, 825-31.

Avrameas, S. (1970). Emploi de la concanavaline-A pour 1'isolement, la détection et la mesure des glycoprotéines et glucides extra- ou endocellulaires. C.R. Acad. Sci. (Paris) 270, $2205-8$. 
AVRAMEAS, S. \& GUILBERT, B. (I97Ia). A method for quantitative determination of cellular immunoglobulins by enzyme-labeled antibodies. Europ. F. Immunol. r, 394-6.

AVRAMEAS, S. \& GUILBERT, B. (I97I $b$ ). Dosage enzymo-immunologique de protéines à l'aide d'immunoadsorbants et d'antigènes marqués aux enzymes. C.R. Acad. Sci. (Paris) 273, 2705-7.

AVRAMEAS, S., TAUDOU, B. \& TERNYNCK, T. (I97I). Specificity of antibodies synthetized by immunocytes as detected by immunoenzyme techniques. Int. Arch. Allergy 40, 161-70.

AVRAMEAS, S. \& TERNYNCK, T. (1969). The cross-linking of proteins with glutaraldehyde and its use for the preparation of immunoadsorbents. Immunochemistry 6, 53-63.

AVRAMEAS, S. \& TERNYNCK, T. (I97I). Peroxidase labelled antibody and Fab conjugates with enhanced intracellular penetration. Immunochemistry 8, II 75 -9.

AVRAMEAS, S. \& URIEL, J. (I966). Méthode de marquage d'antigènes et d'anticorps avec des enzymes et son application en immunodiffusion $C R$. Acad. Sci. (Paris) 262, 2543-5.

BAKER, B. L., PEK, S., MIDGLEY, A. R. \& GERSTEN, B. E. (I970). Identification of the corticotropin cell in Rat hypophyses with peroxidase-labelled antibody. Anat. Rec. 166, 557-63.

BARIETY, J., DRUET, P., LALIBERTE, F. \& SAPIN, C. (I97I). Glomerulonephritis with $\gamma$ and $\mathrm{f}_{1}-\mathrm{C}$ globulin deposits induced in rats by mercuric chloride. Amer. F. Path. 65, 293-302.

BENSON, M. D. \& COHEN, A.S. (I970). Antinuclear antibodies ins sytemic lupus erythematosus. Ann. Int. Med. 73, 943 .

BERENBAUM, M. D. (I959). The autoradiographic localization of intracellular antibody. Immuno$\log y 2,71-83$.

BERNHARD, W. \& AVRAMEAS, S, (I97I). Ultrastructural visualization of cellular carbohydrate components by means of concanavalin-A. Exp. Cell Res. 64, 232-6.

BRETTON, R. \& LESPINATS, G. (I969). Localization ultrastructurale d'antigènes à la surface de cellules tumorales. C.R. Acad. Sci. (Paris) 268, 3223-5.

BRETTON, R., TERNYNCK, T. \& AVRAMEAS, S. (1972). Comparison of peroxidase and ferritin labelling of cell surface antigens. Exp. Cell Res. 7I, $145-55$.

coONS, A. H. (I956). Histochemistry with labeled antibody. Int. Rev. Cytol. 5, I 23.

COONS, A. H. \& KAPLAN, M. H. (1950). Localization of antigen in tissue cells. $\not$. exp. Med. 9 r, r. DRUET, P., LELOUP, B., BARIETY, J. \& LA GRUE, G. (I970). Application à la pathologie rénale de la technique des anticorps couplés aux enzymes. Rev. Europ. Etudes Clin. Biol. $\mathbf{x}_{5}$, II9-22.

ENGVALl, E. \& PERLMANN, P. (I97I). Enzyme-linked immunoadsorbent assay (ELISA) Quantitative assay of immunoglobulin G. Immunochemistry 8, $87 \mathrm{I}-4$.

FUKUYAMA, K., DOUGLAS, S. D., TUFFANELLI, D. L. \& EPSTEIN, W. L. (I970). Immunohistochemical method for localization of antibodies in cutaneous disease. Am. F. Clin. Path. 54, $410-18$.

gonatas, N. K., antoine, J. C., Avrameas, s. \& stibber, A. (1972). Surface immunoglobulins of thymus and lymph node cells demonstrated by the peroxidase coupling technique. Lab. Invest. 26, 253-6I.

GONATAS, N. K. \& AVRAMEAS, S. (1972). Cell affinity labelling with peroxidase conjugates (in preparation).

GRAHAM, R. C. \& KARNOVSKY, M. J. (I966). The early stages of absorption of injected horseradish peroxidase into the proximal tubules of mouse kidney. Ultrastructural cytochemistry by a new technique. F. Histochem. Cytochem. 14, 29I-302.

GUILIIEN, P., AVRAMEAS, S. \& BURTIN, P. (1970). Specificity of antibodies in single cells after immunization with antigens bearing several antigenic determinants. Immunology r8, 483-9r.

GUILlien, P., BURTIN, P. \& AVRameas, s. (I968). Association de l'immunofiuorescecne et de l'immunoenzymologie pour la détection d'anticorps intra-cellulaires. C.R. Acad. Sci. (Paris) 267, $1425-7$.

HU GON, J. \& BORGERS, M. (r966). Ultrastructural localization of alkaline phosphatase activity in the absorbing cells of the duodenum of mouse $\mathcal{F}$. Histochem. Cytochem. 14, 629-40.

JOHNSON, A. B., WISNIEWSKI, H. M., RAINE, C. S., EYLAR, E. H. \& TEARY, R. D. (I97I). Specific binding of peroxidase labeled myelin basic protein in allergic encephalomyelitis. Proc. Natl Acad. Sci. 68, 2694-8.

KAWARAI, Y. \& NAKANE, P. K. (1970). Localization of tissue antigens on the ultrathin sections with peroxidase labelled antibody method. F. Histochem. Cytochem. 18, I6I-6. 
KRAEHENBUHL, J. P., DE GRANDI, P. D. \& CAMPICHE, M. A. (I97I). Ultrastructural localization of intracellular antigen using enzyme labeled antibody fragments. F. Cell Biol. 50, 432-45.

KÜHLMAN, W. \& AVRAMEAS, s. (I97I). Glucose-oxidase as an antigen marker for light and electron microscopic studies. $\mathcal{F}$. Histochem. Cytochem. 19, 36r-8.

KÜHLMAN, W., AVRAMEAS, S. \& TERNYNCK, T. (I972). Comparison of various antibodyperoxidase conjugates for the ultrastructural localization of antigens ( $m s$. in preparation).

LEDUC, E. H., SCOTT, G.B. \& AVRAMEAS, S. (1969). Ultrastructural localization of intracellular immunoglobulins in plasma cells and lymphoblasts by enzyme labeled antibodies. $\mathcal{F}$. Histochem. Cytochem. 17, 2 I I-24.

LEDUC, E. H., WICKER, R., AVRAMEAS, S. \& BERNHARD, W. (I969). Ultrastructural localization of SV $4 \circ \mathrm{T}$ antigen with enzyme labelled antibody. F. Gen. Virol. 4, 609-I4.

MASON, T. E., PHIFER, R. F., SPICER, S. S., SWALLOW, R. A. \& DRESKIN, R. B. (I969). An immunoglobulin-enzyme bridge method for localizing tissue antigens. F. Histochem. Cytochem. $\mathbf{I 7}, 563-9$.

NAKANE, P. K. (I968). Simultaneous localization of multiple tissue antigens using the peroxidaselabeled antibody method. A study on pituitary glands of the Rats. F. Histochem. Cytochem. 16, $557-60$.

NAKANE, P. K. (I970). Classifications of anterior puitary cell types with immunoenzyme histochemistry. $\mathcal{F}$. Histochem. Cytochem. 18, 9-20.

NAKANE, P. K. \& PIERCE, G.B. (I966). Enzyme labeled antibodies. Preparation and application for the localization of antigens. F. Histochem. Cytochem. 14, 929-3r.

NAKANE, P. K. \& PIERCE, G. B. (I967). Enzyme-labeled antibodies for the light and electron microscopic localization of tissue antigens. F. Cell Biol. 33, 307-18.

PEARSE, A. G. E. (1960). Histochemistry: Theoretical and Applied, and Edn. (Churchill: London). PEPE, F. A. (I96I). The use of specific antibody in electron microscopy. Preparation of mercurylabeled antibody. $\mathcal{F}$. biophys, biochem. Cytol. II, 5I5-20.

PETTS, V. \& ROITT, I. M. (I97I). Peroxidase conjugates for the demonstration of tissue antibodies: evaluation of the technique. Clin. exp. Immunol. 9, 407-18.

SILMAN, I. H. \& KATCHALSKI, E. (I966). Water-insoluble derivatives of enzymes, antigens and antibodies. Ann. Rev. Biochem. 35, 873-908.

SINGER, S. J. (I959). Preparation of an electron dense antibody conjugate. Nature, Lond. I83, I523-4.

STERNBERGER, I. A. \& CUCULIS, J. J. (1969). Method for enzymatic intensification of the immunocytochemical reaction without use of labelled antibodies. $\mathcal{F}$. Histochem. Cytochem. 17, Igo.

TERNYNCK, T. \& AVRAMEAS, S. (I972). Polyacrylamide-protein immunoadsorbents prepared with glutaraldehyde. FEBS Letters 23, 24-8.

URIEL, J. (I967). In: Antibodies to Biologically Active Molecules (ed. B. Cinader), pp. I8I-96. Macmillan \& Pergamon: New York.

VAN WEEMEN, B.K. \& SCHUURS, A. H. W. M. (197I). Immunoassay using antigen-enzyme conjugates. FEBS Letters $15,232-6$.

WELINDER, K. G., SMILIIE, L. B. \& SGHONBAUM, G.R. (1972). Amino-acid sequence studies of horseradish peroxidase. Can. F. Biochem. 50, 44-90.

WICKER, R. (I97 I). Comparison of immunofluorescent and immunoenzymatic techniques applied to the study of viral antigens. Ann. N.Y. Acad. Sci. (USA) 177, 490-500.

WICKER, R. \& AVRAMEAS, S. (I969). Localization of virus antigens by enzyme-labeled antibodies. 7 . Gen. Virol. $4,465-7$ I.

WICKER, R. \& AVRAMEAS, s. (1970). Application de l'autoradiographie associée aux techniques immuno-enzymatiques à l'étude des antigènes et des anticorps. C.R. Acad. Aci. (Paris) 270, $43 I-3$.

WILLINGHAM, M. C., SPICER, S. S. \& GRABER, D. C. (197I). Immunocytologic labeling of calf and human lymphocyte surface antigens. Lab. Invest. 25, 21 I-I9.

WOLFF, K. \& SCHREINER (I97I). Ultrastructural localization of pemphigus antibodies within the epidermis. Nature, Lond. 229, 59-6I.

ZEROMSKI, J. ( I970). Immunological findings in sensory carcinomatous neuropathy. Application of peroxidase labelled antibody. Clin. exp. Immunol. 6, 633-7. 